\title{
Orfandade, movimento, PRESEnÇA
}

\author{
Sobre uma ética da literatura em Putas asesinas, de Roberto Bolaño
}

Wanderlan Alves ${ }^{1}$

\begin{abstract}
Resumo: Este artigo analisa como se expressa uma ética da literatura em três contos de Putas asesinas, de Roberto Bolaño: "Ojo Silva", "Días de 1978" e "Vagabundo en Francia y Bélgica", a partir da errância, do deslocamento e do não pertencimento. Por essa via, na literatura de Bolaño emerge uma ética pautada na busca do artista, da arte e da escritura, como aposta na liberdade capaz de articular a curiosidade, a sensibilidade e a racionalidade, convertendo-as em alternativas para se alcançar um estado estético que se apresenta como lugar em que vida e arte se encontram, na precariedade da linguagem, estabelecendo uma intersecção entre ética e estética.
\end{abstract}

Palavras-chave: Roberto Bolaño; ética; errância; não pertencimento; Putas asesinas; deslocamento

AвStRACt: This article analyzes how an ethics of literature is expressed in three short stories of Roberto Bolaño's Putas Asesinas, "El Ojo Silva", "Días de 1978" and "Vagabundo en Francia y Bélgica", mainly from motifs such as wandering, displacement and disbelonging. An ethics featured by searching for the artist, art and writing emerges from Bolaño's literary work, as a commitment to freedom, able to articulate curiosity, sensibility and rationality, turning them into alternatives to get an aesthetic state that presents itself as a place where life and art approximate themselves, in a precarious language that establishes a relation between ethics and aesthetics.

KEYwORDS: Roberto Bolaño; ethics; wandering; disbelonging; Putas asesinas; displacement

Tenho cinquenta anos e sempre vivi livre; quando morrer, quero que digam de mim: aquele que nunca pertenceu a nenhuma escola, a nenhuma Igreja, a nenhuma instituição, a nenhuma academia, sobretudo a nenhum regime, a não ser o regime da liberdade.

(Gustave Courbet, 23 de junho de 1870, carta a Maurice Richard, ministro das Belas-Artes em Paris)

As palavras em epígrafe, escritas pelo pintor francês Gustave Courbet mais de um século antes da morte de Roberto Bolaño em 2003, parecem ajustar-se perfeitamente àquilo que o escritor chileno praticou e defendeu ao longo de toda a sua obra. Hipoteticamente, poderiam figurar, em forma de síntese, numa declaração do autor, já ao fim da carreira e da vida, sobre si e sobre a literatura que criou.

O não pertencimento - assim como a defesa do direito ao não pertencimento - é um dos traços definidores das personagens, das situações dramáticas e das próprias projeções biográficas do autor em seus textos, aspectos que perpassam diferentes narrativas de sua obra, bem como se metamorfoseiam em outras - como se nota entre as partes do imenso romance 2666, por exemplo. Nesse sentido, há um desejo de absoluta liberdade que percorre sua (bio)grafia, na qual a solidão e a orfandade, assim como o deslocamento permanente e, ao mesmo tempo, um sentimento de presença (por vezes obscuro) conotado pela voz, por um rastro, por uma lembrança, por uma fala ou, mesmo, pelo silêncio, produzem um amálgama de sentidos e sensações que apontam para a escritura e a literatura como uma aposta do indivíduo (e de Bolaño) em uma trajetória incerta em busca da liberdade. É a pergunta em torno da potência da literatura que irrompe em sua escritura. Como lembra Diana Klinger,

1 Doutor em Letras pela UNESP/SJRP, professor de literaturas hispânicas da Universidade Estadual da Paraíba e docente permanente do Programa de Pós-graduação em Literatura e Interculturalidade (PPGLI/UEPB). E-mail: alveswanderlan@yahoo.com.br. 


\section{1}

Há pelo menos três coisas que aparecem insistentemente nos romances e contos de Bolaño. Um é justamente a associação entre a literatura e o mal. Ela é evidente em alguns dos primeiros romances como A literatura nazi nas Américas ou Estrela distante. A outra, a questão do exílio, ou talvez fosse melhor dizer, da errância. Pois, apesar de Bolaño ter abandonado definitivamente o Chile depois da derrota de Allende, sempre se recusou a ser considerado exilado, e seus personagens escritores vivem a vida em eterno deslocamento ou permanente fuga. A terceira (entre outras) das coisas que aparecem recorrentemente são os personagens autores, poetas ou críticos literários que ora desaparecem, ora se tornam detetives na procura de um autor desaparecido (KLINGER, 2014, p. 135).

Em Putas asesinas, coletânea de contos publicada em 2001, motivos relacionados ao movimento ou deslocamento (físico-espacial e temático), à solidão e à impossibilidade de o indivíduo fixar-se em um lugar ou fixar sentidos estáticos para suas ações ou para aquilo que percebe ou imagina acerca do outro figuram na totalidade dos relatos, constituindo-se, deste modo, num dos temas centrais tratados no livro. De certa maneira, ao articular o não pertencimento a locais, grupos, nacionalidades e idiomas - o espanhol dos textos de Bolaño coaduna-se à ideia de um idioma internacionalista que chega a soar, por vezes, artificial - ao devir estético potencializado pela associação de uma sensibilidade, em geral identificada à figura do narrador, que tenta obstinadamente captar o informe ao mesmo tempo em que procura racionalizar tais percepções na linguagem na/da narrativa, a escritura em Putas asesinas figura como um lugar de onde emerge uma ética possível da/na literatura.

Centrando-nos em três contos do livro, a saber, "El Ojo Silva", "Días de 1978" e "Vagabundo en Francia y Bélgica", sem perder de vista o resto da coletânea, procuramos, a seguir, mostrar como a opção pela marginalidade constitui-se numa via pela qual os narradores desses contos - todos eles são uma espécie de alter ego do próprio Bolaño - esboçam as bases para uma ética que corresponde à do próprio autor em sua trajetória, além de reivindicar, para o campo estético, uma autonomia que se, por um lado, pode soar anacrônica em nossa época, por outro, pode significar a sobrevivência (DIDI-HUBERMAN, 2011) de um potencial simultaneamente ético e estético da arte, na literatura contemporânea. Nesse sentido, é uma ética do artista em primeiro lugar, mas, à medida que sua aposta incursiona na ideia de autonomia do objeto artístico, devém, também, em uma ética da própria arte e, neste caso, da literatura.

\section{A errância, o inapreensível, o silêncio}

"El Ojo Silva" é o conto que abre Putas Asesinas e, a julgar pelas primeiras frases do texto, parece uma narrativa cuja história narrada tratará de exilados chilenos no contexto da ditadura de Pinochet:

Lo que son las cosas, Mauricio Silva, el Ojo, siempre intentó escapar de la violencia, aun a riesgo de ser considerado un cobarde, pero de la violencia, de la verdadera violencia, no se puede escapar, al menos nosotros, los nacidos en Latinoamérica en la década de los cincuenta, los que rondábamos los veinte años cuando murió Salvador Allende (BOLAÑO, 2001, p. 11). 


\section{1\}}

Na verdade, o horror associado à ditadura chilena percorre o conjunto de relatos do livro, como uma sombra ou como o que não se pode esquecer e que, de repente, emerge através de uma imagem, uma data, uma referência, uma associação livre, etc. Nesse sentido, há, desde o início, na narrativa desse conto, uma matéria que se impõe. Se levarmos em consideração que em sua obra Bolaño se distancia de modo contundente de uma literatura que aposte naquilo que poderia ser qualificado pelo mercado como "literatura engajada" - pois o autor odeia o mercado e sua força de ação e determinação sobre a literatura -, notaremos, pois, que os motivos, as imagens e os restos de histórias envolvendo a ditadura irrompem no relato como o mal que não desaparece do horizonte do narrador, mesmo quando os eventos narrados são focalizados numa visão "por detrás" (POUILLON, 1974). Mas, além disso, constituem-se, também, num desafio que Bolaño se impõe como escritor: cabe-Ihe dobrar a matéria por meio da forma por um ato de maestria, pois, para dizê-lo de um modo afim à concepção de Schiller (1995), em A educação estética do homem, "pela forma, ele destrói sua matéria" (SCHILLER, 1995, p. 116). Ao insistir no valor intrínseco do literário, Bolaño se debate com a defesa da autonomia da literatura em face do mercado - aspecto meio quixotesco que percorre toda a sua obra -, ao mesmo tempo em que, nessa defesa, se pauta num valor de imanência do literário, que, para ele, justificaria a permanência, difusão e força de uma determinada obra para gerar leituras.

Nesse sentido, a postura de Bolaño acerca das relações da literatura com o mercado "representa este último avatar da autonomia e, embora visualize com bastante nitidez esse futuro da literatura como negócio, produto, se empenha em jogar o jogo da luta pela autonomia, da insistência no valor da literatura que ainda não se dobrou às exigências exteriores" (MAGRI, 2013, p. 25). No que tange à aposta no poder da literatura enquanto imanência, por sua vez, Bolaño se introduz por um caminho em que o literário se "encerra numa intransitividade radical" (FOUCAULT, 2007, p. 416) que afirma permanentemente sua existência. Como notara Foucault a respeito dessa perspectiva autônoma e moderna para a literatura que se afirmou ainda no início do século XIX, frente à tendência instrumental que a incorporava às suas leis, ela "reaparece sob uma modalidade estritamente oposta: silenciosa, cautelosa deposição da palavra sobre a brancura de um papel, onde ela não pode ter nem sonoridade, nem interlocutor, onde nada mais tem a dizer senão a si própria, nada mais a fazer senão cintilar o esplendor do seu ser" (FOUCAULT, 2007, p. 416). Quanto a esse movimento, a postura de Bolaño mostra-se, hoje, "anacrônica" (DIDI-HUBERMAN, 2011), o que talvez se inscreva num certo potencial de resistência do literário, ao qual o escritor se apega como tábua de salvação, mas que também lhe serve de via de instalação da dúvida sobre instituição literária e também de perspectiva autocrítica.

Nesse primeiro conto do livro, por mais que a história narrada remonte à ditadura chilena, em janeiro de 1974, é a errância que se impõe e estrutura o relato. O perambular de Ojo pelo Chile, a Argentina, o México, Paris, Berlim e a Índia, seus encontros em diferentes lugares com o narrador (em bares, jornais, cafés e praças) e o substrato da condição de exilados de ambos vão articulando o exílio ao vagar, internamente ao que é narrado, e, por essa via, se imbricam afecções do artista e da política na personagem e no narrador. Por mais que nenhum deles se vanglorie de ter participado da militância de resistência política, no Chile, tal condição não os abandona, pois é, também, por ela que eles se tornaram homens do mundo, para empregar uma expressão de Baudelaire (1997). No entanto, esse é mais um traço de suas biografias que se converte em signo - nesse caso, signo da precariedade: destinos incertos, trabalhos incertos, endereços incertos. A 


\section{1}

única certeza que se lhes afigura é a errância, que é ambígua, já que se liga, simultaneamente, à fuga e a um salto rumo à dissonância e ao desconhecido, a seus próprios agora que, talvez, poderíamos identificar com a ideia e a busca de liberdade, mas que por vezes também se aproxima da loucura - como fica claro, por exemplo, em "Días de 1978". É, portanto, sob o signo da falta que a liberdade se apresenta, em "El Ojo Silva", como um valor absoluto e inalienável cujo sentido da perda fomenta a sua reconstituição, na literatura.

Para Schiller, a liberdade

tem seu início somente quando o homem é completo e já desenvolveu seus dois impulsos fundamentais [sensível e formal]; ela tem, pois, de faltar, enquanto ele for incompleto e um dos princípios estiver excluído, mas ela tem de poder ser reconstituída por tudo aquilo que pode torná-lo de novo completo (SCHILLER, 1995, p. 105).

Sob certo ângulo, então, por mais que se note um tom melancólico e pessimista neste conto, assim como em toda a obra de Bolaño, vislumbra-se nele, também, uma espécie de trajetória de aprendizagem (ou de negatividade) que é responsável pela afirmação de um sentido de liberdade para o indivíduo - na narrativa, Ojo e o narrador. Trata-se, conforme comenta leda Magri, de seu modo de colocar o problema, isto é, "o de um escritor que enxerga o problema de não haver saídas sem viseiras nos olhos, mas segue buscando uma saída” (MAGRI, 2013, p. 29). Ao mesmo tempo, esse modo de enfrentar o problema se inscreve numa utopia da forma, uma vez que a alternativa aos limites da existência e da própria literatura se coloca no âmbito da estética, entendida como aquilo que conduz ao ilimitado e, portanto, também à liberdade, universo que se volta "para a seriedade e para o jogo, para o repouso e para o movimento, para a brandura e para a resistência, para o pensamento abstrato e para a intuição" (SCHILLER, 1995, p. 114).

Essa liberdade da/na literatura é o que justifica, internamente à história narrada, o narrador passar, bruscamente, em "El Ojo Silva", dos comentários envolvendo um aspecto político - a condição de exilado da personagem e a ditadura de Pinochet, por exemplo - a questões relacionadas às preferências de Ojo sobre modos de vestir, ou deter-se na observação de que a personagem era a única pessoa que, entre os seus colegas, usava gravata, quando viveram na mesma época, no México, cada um trabalhando num jornal - Ojo é um fotógrafo. Enquanto universo aberto ao ilimitado, no estado estético, se quisermos manter a terminologia de Schiller (1995), a escritura se permite ir e vir, perambular, como a personagem e o narrador, rumo a temas, assuntos e motivos diversos, de modo quase "displicente", frustrando, por vezes, as expectativas criadas na própria história narrada, ao passar a outros temas depois de ter deixado a impressão de que algo importante estava na iminência de ocorrer - como se nota, por exemplo, em "Gómez Palacio" ou "Últimos atardeceres en la tierra", em Putas asesinas. Trata-se, na verdade, de um procedimento frequente nos contos de Bolaño (HERRERA-ÁLVAREZ, 2010), que o distancia, por exemplo, da perspectiva de Poe para o relato breve, pautado na intensidade, na economia e na unidade de efeito.

Ao contrário, Bolaño investe num processo de amplificação, dispersão e desperdício que confere à sua poética uma indeterminação constitutiva: muitos de seus relatos são genericamente indefinidos, entre o conto, o ensaio, a conferência. Também são indefinidos em relação à própria estrutura, cujo final mostra-se, por vezes, abrupto, de modo que as histórias narradas costumam interromper-se, em vez de concluir-se, como que aleatoriamente, o que sugere, por outro lado, 


\section{1}

que poderiam estender-se quase infinitamente. Em "Días de 1978", quase ao final, o narrador comenta, por exemplo: "Aquí debería acabar este relato, pero la vida es un poco más dura que la literatura” (BOLAÑO, 2001, p. 78). E a história narrada continua. Segundo Gutiérrez, que identifica essa técnica em Bolaño com o neobarroco, ela pode ser de dois tipos: a) a descrição, quando é empregada para descartar o vazio, a "fala [...] aparentemente sem conexão, de palavras e ideias que pulam de forma indiscriminada de um tema a outro" (GUTIÉRREZ, 2007, p. 7); e b) a amplificação, quando as micro-histórias que compõem os relatos vão ganhando autonomia interna ou vão ramificando-se, de modo que tanto o estendem quanto potencializam novas histórias, a partir de uma ideia criativa pautada na multiplicidade. Deste modo, a "intensidade cria um discurso múltiplo, que se amplia, saturado, mas que não leva a lugar nenhum: 'ética do desperdício', 'transgressão do útil' [...]. O discurso perde sua função e seus referentes, desloca-se, a linguagem tende para seu limite, perde sua forma estática" (GUTIÉRREZ, 2007, p. 8).

Esse recurso consiste numa abertura à imaginação, algo fundamental para o universo de indivíduos que, como Ojo e o narrador, já não têm a quê apegar-se (nem pátria, nem ideal político, nem família, por exemplo), e encontram na imaginação uma via para expandir o alcance da própria vida. O narrador o faz pelo ato de narrar, enquanto Ojo o faz a partir de seu ofício de fotógrafo. Ambos, por sua vez, vinculam seu ofício à viagem, como se viajar e narrar constituíssem etapas de uma mesma trajetória (pessoal, imaginativa e ficcional). É também nesse sentido que sua condição de tensão com o mundo à sua volta os inscreve numa questão ética, pois o homem ético é, por definição, problemático (SCHILLER, 1995), aspecto que se coaduna, por sua vez, às suas trajetórias como narradores - ainda que Ojo não seja o narrador do relato, ele narra, no conto, para o narrador, as aventuras e angústias que vivera na Índia.

Se pensarmos, por exemplo, nas considerações de Lukács (2009) sobre o indivíduo problemático - que não tem lugar na sociedade burguesa, porém (ou por isso mesmo) é fundamental na constituição do romance moderno -, cujo choque com seu mundo, ao qual não pode se integrar, fomenta o deslocamento que o leva à viagem como alternativa para o autoconhecimento, mas também como escape dos espaços sociais institucionalizados que tentam submetê-lo, poderemos constatar que perambular e narrar são atitudes complementares, na narrativa desse conto. Enquanto no romance, tal como teorizado por Lukács (2000), é quando o caminho termina que começa a viagem, isto é, o narrar ou o romance (enquanto devir), em "El Ojo Silva", assim como na maioria das narrativas de Bolaño, visto que o caminho nunca termina, pois o vagar das personagens é perpétuo, também nunca termina o narrar. Tal condição da vivência das personagens e dos narradores constituise, pois, na razão estrutural para o esforço por "descartar o vazio" e "amplificar" o relato (GUTIÉRREZ, 2007), indefinidamente.

Não por coincidência, a personagem Ojo é uma espécie de dândi, mas também um estranho (raro, em espanhol, com todo o peso que a figura do raro porta para certo perfil de literato, na América Latina), e sua excentricidade se deixa ver no modo de vestir, em traços de uma homossexualidade levemente reprimida e, principalmente, em sua característica de viajante. Na figura de Ojo se amalgamam o dândi, o artista, a criança, figuras que, ao menos desde Baudelaire (1997), apontam, simultaneamente, para o homem livre e para um ideal estético, ancorado naquilo que Schiller (1995) definiu como impulso lúdico, visto que a "disposição lúdica' suscitada pelo belo é um estado de liberdade para o homem" (SUZUKI, 1995, p. 17). Nesse sentido, a liberdade da forma estética corresponde, na narrativa de Bolaño, à liberdade do indivíduo. 


\section{1}

Ao conferir, via narração, liberdade para a conformação do próprio relato, o narrador (e, internamente, também Ojo narrador) confere liberdade a si mesmo. Se, para Schiller (1995), o estado de natureza, que ele associa à liberdade, é típico da infância, disso resulta um imperativo, que é converter essa natureza/infância/liberdade em estado ético. É o que, de certo modo, fazem esses narradores, em "El Ojo Silva", por meio de um exercício de aproximação, um girar em torno de, que Ihes abre espaço à vivência e à imaginação, um convite ao exercício da sensibilidade (percepção, portanto) e da racionalidade (que pode orientar e estruturar o que narram, isto é, a forma). Essa perspectiva distancia o relato de referentes concretos, ao passo que afirma uma presença, nem sempre clara ou comunicável para/pelas personagens ou, mesmo, o narrador.

O narrar se torna, deste modo, um perambular perpetuamente, são narradores e personagens que vão pelas ruas, cidades e países em carros, trens, aviões ou a pé, e relatos que vagueiam ao redor de um tema, uma impressão ou uma especulação - em "Vagabundo en Francia y Bélgica", por exemplo, a trajetória do narrador é traçada por sua busca de informações e materiais sobre Henri Lefebvre, a partir do momento em que encontra um texto do francês numa revista intitulada Luna Park, que ele descobre casualmente numa livraria de livros usados, em Paris. O que resta, nesse percurso incerto, constitui-se, pois, num rastro de si, na afirmação de uma presença, como se esse fosse o preço a pagar pelo não pertencimento, a existência captada apenas no movimento incessante de seu ir e vir, potência expressiva de um devir apenas precariamente apreensível na arte, na literatura, no narrar:

Con el paso del tiempo empezó a olvidar hasta su rostro, aunque siempre persistió en mi memoria una forma de acercarse, un estar, una forma de opinar desde cierta distancia y desde cierta tristeza nada enfática que asociaba con el Ojo Silva, un Ojo Silva que ya no tenía rostro o que había adquirido un rostro de sombras, pero que aún mantenía lo esencial, la memoria de su movimiento, una entidad casi abstracta pero en donde no cabía la quietud (BOLAÑO, 2001, p. 14).

Internamente ao relato, é a fotografia que figura como modo de tentar reter um momento, ao mesmo tempo em que rompe ou desmascara um estado de barbárie, no narrado. Ao deparar-se com uma espécie de templo de aspecto prostibular, no submundo de uma cidade indiana não nomeada, onde meninos eram castrados por razões religiosas, para adoração a um deus, conta Ojo e, depois de ouvi-lo, comenta o narrador:

Saqué mi cámara, dijo, y le hice una foto. Sabía que estaba condenándome por toda la eternidad, pero lo hice. [...]

Ignoro cuánto rato estuvimos en silencio. Sé que hacía frío pues en algún momento me puse a temblar. A mi lado oí sollozar al Ojo un par de veces, pero preferí no mirarlo. Vi los faros de un coche que pasaba por una de las calles laterales a la plaza. A través del follaje vi encenderse la ventana (BOLAÑO, 2001, p. 20).

Nesse sentido, o estético em Bolaño, assim como para Schiller, também faz as vezes de uma ética "que vem completar o sistema moral" (SUZUKI, 1995, p. 18), apesar de o pessimismo do 


\section{1 -}

escritor chileno não deixar pistas que apontem para um estado de virtude e felicidade a ser alcançado pelo indivíduo, ao contrário do idealista alemão.

Depois de muitos anos sem se ver, Ojo e o narrador se reencontram em Paris, onde este estava, por ocasião de uma conferência sobre um livro seu. Após perambularem pela cidade, à noite, passando por diversos bares, enquanto conversam, os dois voltam em direção ao hotel onde o narrador está hospedado. Então, Ojo conta-lhe uma história que ocorreu quando esteve na Índia, país a que tinha ido por seu trabalho como fotógrafo de uma revista parisiense, que estava fazendo uma série de reportagens sobre prostituição e o enviou para fotografar um "bairro de putas" em solo indiano. O que se narra, a partir de então, no conto, é seu itinerário ao longo dessa viagem marcada pelo choque do ou com o horror e o mal e pelo pesadelo da perseguição (que, é bom lembrar, talvez os tenha acompanhado ao longo de toda a vida, em sua condição de exilados). É nesse contexto que a arte (fotografia ou narrativa) aparece como recurso para tentar captar o instante, no conto.

Ante o horror daquilo que Ojo the conta que viveu e que, de certo modo, a fotografia captura precariamente, ambos se deparam com algo que não podem encarar. Gutiérrez observa que "por trás de uma linguagem aparentemente simples, neutra, direta e superficial, Bolaño nos fala do que se esconde no fundo do abismo: o vazio, a angústia da existência, o mal, a violência, a parte mais obscura da história recente da América Latina" (GUTIÉRREZ, 2007, p. 23), enumeração que poderia ir seguida de reticências.

Não por coincidência, o narrador comenta, no fragmento acima, que não se olham, ainda que Ojo chore e ele procure tentar distrair-se com o movimento na rua. Contrastando com o movimento incerto e perpétuo que caracteriza suas vidas e trajetórias, o estático e o fixo (capturado na fotografia, mas incrustado no templo e no menino castrado de que fala Ojo) parecem conotar o vazio do qual mal podem se aproximar, mas do qual também não podem livrar-se, depois de tê-lo vislumbrado. A sua condição de não pertencimento se alia, então, à de malditos que, em sua busca por liberdade, por vezes deparam-se com o horror do qual, em meio à busca, tentam fugir (mas isso é impossível, para eles), o que também conota certa crueldade instalada ou expressa na literatura, seu copertencimento com o mal, na obra de Bolaño.

O perambular torna-se, deste modo, ainda mais ambíguo, à medida que oscila entre a busca pelo desconhecido e a fuga provocada pelo choque do/com o desconhecido. Em certa medida, Ojo, o narrador e o menino castrado aproximam-se por analogia: o exilado, o artista e a castração são traços simbólicos que se relacionam a todos eles. Os três convertidos momentaneamente em destaques de um evento passageiro que, quando acaba, volta a colocálos à margem, de onde talvez nunca tenham saído. Tal analogia se reveste de um sentido político se lembrarmos que Ojo e o narrador (assim como Bolaño) militaram na resistência à ditadura no Chile, após o golpe de 1973. Sobre a criança, no relato, Ojo explica: "Semanas después, cuando todo ha acabado, el niño vuelve a casa, pero ya es un castrado y los padres lo rechazan" (BOLAÑO, 2001, p. 19). Então, ele(s) é(são) condenado(s) à margem, ao submundo, a perambular infinitamente.

Depois de conhecer o menino castrado no templo indiano e ficar perplexo com o que viu, Ojo foge levando-o e também leva outra criança, um menino que estava destinado à mesma mutilação, no dia seguinte. A partir desse momento, viaja por terras desconhecidas, fugindo, pois pensa que a polícia o está perseguindo, sem perceber que, na verdade, viaja em espiral e não chega a distanciar-se tanto de onde partira. Vive por um tempo com os dois meninos numa espécie de 


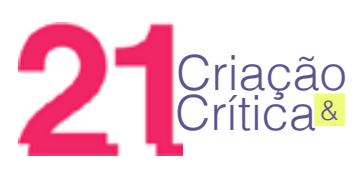

aldeia, cuidando das crianças como filhos - apresenta-se, de fato, às pessoas do local como sendo seu pai. Mas a expectativa de um desfecho positivo pelo leitor frustra-se, pois ambas as crianças morrem vitimadas por uma epidemia. Ao voltar para a cidade onde ficava o templo, descobre que o local foi fechado e transformado numa espécie de cortiço. Depois de um tempo, volta à Europa, com a ajuda de um amigo que lhe manda as passagens. De tudo isso lhe restam, então, apenas as vivências, o deslocamento e certa melancolia que se expressa no choro. Quando Ojo liga para seu amigo francês, relata o narrador no último parágrafo do conto:

su amigo francés le dijo que sí, que por supuesto, que lo haría de inmediato, y también dijo ¿qué es ese ruido?, ¿estás llorando?, y el Ojo dijo que sí, que no podía dejar de llorar, que llevaba horas llorando. Y su amigo francés le dijo que se calmara. Y el Ojo se rió sin dejar de llorar y dijo que eso haría y colgó el teléfono. Y luego siguió llorando sin parar (BOLAÑO, 2001, p. 25).

O desfecho constitui-se, pois, numa síntese do itinerário do exilado, e também do artista conforme esse é concebido por Bolaño: aquele que não tem lugar. A tensão entre algo que parece eterno (essa condição à margem) e algo transitório que lhe é próprio não deixa de ser expressiva, também, da concepção estética à qual, desde o início deste texto, insistimos que Bolaño se apega, em sua escrita, e que poderíamos vincular tanto a Schiller (1995) quando a Baudelaire (1997), por exemplo. A figura do melancólico, aliás, ao final do relato, opera uma interrupção no curso do tempo, algo como um dispositivo que possibilita o encontro de tempos e permite a Ojo, mas também ao narrador, formar uma representação de si, dos eventos vivenciados ou narrados e, deste modo, captarem o peso de sua existência, em sua narração. No devir estético, modificamse como indivíduos, mas permanecem os mesmos. Nessa tensão entre o eterno e o transitório, existem, ou são, ainda que por momentos.

Em "El Ojo Silva" o caráter inapreensível das percepções, das sensações ou mesmo daquilo que parece estar além do humano aparece associado à errância das personagens e do narrador. Já em "Días de 1978", por sua vez, o inapreensível irrompe como o detonador dos conflitos que se instalam entre as personagens e entre elas e o narrador. De modo semelhante ao conto de abertura do livro, são também o exílio e a ditadura que circunscrevem o universo da história narrada: "En cierta ocasión B asiste a una fiesta de chilenos exiliados en Europa. B acaba de llegar de México y no conoce a la mayoría de los asistentes" (BOLAÑO, 2001, p. 65).

Como se nota, os motivos se repetem - solidão, isolamento, a condição de estrangeiro. O que singulariza tanto as relações entre as personagens fundamentais, neste conto, quanto a própria escrita é o jogo com o inapreensível, por meio de uma impressão, um olhar, um conflito que se instaura entre dois indivíduos, mas mal se expressa em gesto, ação ou linguagem. Na mesma festa,

En determinado momento, posiblemente al amanecer, un joven se encara con $\mathrm{B}$ utilizando un pretexto cualquiera. La discusión es lamentable e inevitable. [...] Pero cuando la pelea es inminente, B se levanta y rehúsa el enfrentamiento. $U$ lo insulta, lo desafía, golpea la mesa (tal vez la pared) con el puño. Todo inútil.// B no le hace caso y se marcha (BOLAÑO, 2001, p. 66). 


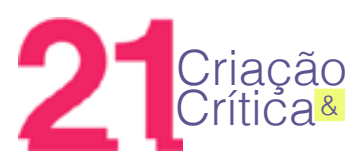

O desentendimento, que se inicia como mera briga desencadeada pelo possível estado de embriaguez de $U$, pouco a pouco se afasta da concretude que poderia associá-lo, por exemplo, ao jogo de forças entre dois homens, ofuscando-se em meio a pinceladas que turvam a situação dramática: a briga começa "por um pretexto qualquer". No entanto, "a discussão é lamentável e inevitável". Por quê? O narrador não esclarece, apesar de apontar para a fatalidade. B responde à violência crescente e iminente de $U$ de modo não menos violento, ainda que apenas no plano simbólico: ignora-o e vai embora. Em seu gesto, o protagonista inscreve uma superioridade que porta certo ar esnobe ou blasé. Não fica claro se foge de U por precaução, pois acabara de chegar e não conhece ninguém nesse meio, ou se, de fato, a recusa ao enfrentamento significa algo mais (vaidade, egoísmo?).

O gesto estético de $\mathrm{B}$, no sentido de uma pretensa superioridade deliberada que poderia coadunar-se ao dandismo e à flânerie, acaba conotando, também, aquilo que a linguagem não é capaz de expressar ou de racionalizar, e cuja sensibilidade apenas parcialmente pode captar. Deste modo, o protagonista sabe que não deve enfrentar $U$, mas não é capaz de esclarecer, de fato, as razões que o fazem sair à francesa da festa. Ao mesmo tempo, se despojada da aparente superioridade, sua postura se assemelha à caracterização que o narrador de "El Ojo Silva" fizera do protagonista logo no início do conto de abertura da coletânea: alguém que está sempre tentando fugir da violência, mas isso se mostra impossível para indivíduos como ele(s).

Como em "El Ojo Silva", a impressão é a de estar sempre fugindo ou buscando (algo e nada, ao mesmo tempo) e, nesse sentido, resistindo (RANCIĖRE, 2007), na medida em que parece anular quaisquer impulsos práticos em nome do movimento, espécie de jogo arriscado, porque põe em jogo a própria vida, marcada pela solidão: "El más pobre de los chilenos residentes en Barcelona y también, probablemente, el más solitario" (BOLAÑO, 2001, p. 66). As próprias escoIhas do narrador corroboram o sentido daquilo que não se pode apreender totalmente, a partir da dúvida que se instala em suas afirmações (provavelmente, talvez, etc.), que rompem com o status mais característico do narrador onisciente enquanto autoridade no/do relato.

Depois da briga (que não acontece), o desenvolvimento da história narrada ocorre a partir daquilo que o narrador imagina sobre $U$ e sua mulher, além do que especula sobre os dois nos momentos em que, por casualidade, os encontra nas ruas de Barcelona. O relato configura-se, pouco a pouco, como uma espécie de paisagem, mas não uma paisagem realista, naturalista ou, ao contrário, impressionista, e sim uma paisagem formada de luz e sombras - que, quanto ao estilo, se aproxima mais do neobarroco e do próprio barroco -, na qual aquilo que se deixa ver se constitui apenas numa ponta do iceberg. Como lembra Rafael Gutiérrez, a

linguagem de Bolaño [...] está sempre no limite da tensão, assim como seus diálogos e suas histórias, sempre à beira de um abismo, sempre transitando nessa iminência de que fala Borges. As palavras tentam traduzir uma coisa que sempre escapa, que está aí, mas é inapreensível, ou pelo menos racionalmente inapreensível (GUTIÉRREZ, 2007, p. 2).

Os conflitos que se instalam entre as personagens são como novelos que supostamente poderiam ser desenrolados, porém elas não são capazes de fazer isso. Não por coincidência, $U$, a esposa e seus amigos praticamente não falam de si, e quando o fazem, parecem não chegar, de 


\section{1}

fato, ao ponto desejado: "lo cierto es que la imagen de ambos [U e a esposa, para B], enmarcada en aquella fiesta lamentable, perdura en su memoria de forma misteriosa, como si estuviera allí para decirle algo, que es importante, pero que B, por más vueltas que le da, no sabe qué es" (BOLAÑo, 2001, p. 68). A hipótese de um destino (“como si estuviera allí para decirle algo"), entretanto, se choca com a ausência de uma teleologia ou mesmo de qualquer expectativa de futuro.

Esse procedimento de, por meio de silêncios e entreditos, apontar para aquilo que a linguagem e a racionalidade não conseguem apreender alcança seu ponto culminante já quase ao final da história narrada, quando $B$ decide fazer uma visita a $U$ e sua esposa - talvez por ter percebido que muito de suas impressões em relação a $U$ se devia ao incidente na festa. Ao chegar, levando uma garrafa de vinho para comemorar com os compatriotas, depara-se com um universo fechado, em que se expressam apenas estilhaços de eventos e sensações. Estão todos fechados em si mesmos e para si mesmos:

La bruja y la dueña de la casa están encerradas en el estudio del dueño de la casa. La chica pálida, el dueño de la casa y la mujer de U están encerrados en la cocina. El novio de la chica pálida y la dueña de la casa están encerrados en el dormitorio. La mujer de U y la chica pálida están encerradas en el baño. La bruja y el dueño de la casa están encerrados en el pasillo, lo que ya es mucho decir. jIncluso en uno de los vaivenes el propio $B$ se ve a sí mismo encerrado en la habitación de invitados con la dueña de la casa y la chica pálida [...] (BOLAÑO, 2001, p. 72).

Uma espécie de ambientação reflexa da psicologia das personagens se deixa entrever no espaço e no ambiente da casa. Logo depois $B$ descobre que nesse mesmo dia $U$ tinha tentado suicidar-se. Porém há algo mais, um mal-estar que se manifesta justamente como aquilo que escapa à compreensão. Diferentemente de "El Ojo Silva", em que o movimento, que oscila entre a busca e a fuga, se expressa na viagem, em "Días de 1978" esse movimento de busca e fuga acontece pela alternância de silêncios e deslocamentos, seja entre as personagens, seja entre elas e aquilo que o narrador conta. No ordinário de suas vidas intranquilas, são os pequenos gestos e os pequenos eventos que criam os maiores impactos em suas vidas ou em suas percepções. Dois exemplos são emblemáticos a esse respeito. O primeiro deles, pouco antes da despedida de B, no dia da visita já referida:

Y luego se desata (o más propiamente se desprende) un movimiento en apariencia insignificante, un movimiento claramente de reflujo: B observa, sin moverse del sillón en que está sentado, cómo todos los que hasta hace un momento discutían y parlamentaban en pequeños grupos se dirigen en fila india hasta el dormitorio de los dueños de la casa, excepto la chica pálida [...]. La puerta del dormitorio se cierra. Se acaban los ruidos en sordina (BOLAÑO, 2001, p. 73).

No fragmento acima, o extraordinário é a mudança brusca da atmosfera da casa, que, de repente, passa a conotar uma calmaria e tranquilidade que contrasta com a situação anterior. A segunda situação, por sua vez, mostra-se mais dramática. Aparentemente $U$ teria superado as angústias que o levaram a tentar suicidar-se. Então ele resolve ir a Paris, para visitar um antigo 


\section{1}

companheiro de partido. Nada aparentemente anormal na vida de um exilado em Barcelona. No meio da viagem, entretanto, $U$ decide descer do trem numa estação qualquer, liga para casa, mas não consegue falar com a esposa, liga para um amigo e diz que perdeu a vontade de seguir viagem. Aparenta estar tranquilo. Porém não volta a ligar. Decide continuar a viagem, mas, de repente, começa a caminhar pelo povoado e, então, toma o caminho contrário e entra na mata:

Al día siguiente un campesino lo encuentra colgando de un árbol, ahorcado con su propio cinturón, una empresa no tan fácil como a vista simple puede parecer. El pasaporte, los demás papeles de U, el carnet de conducir, la cartilla de la Seguridad Social, los gendarmes los localizan mientras caminan por el bosque o como si los hubiera intentado esconder (BOLAÑO, 2001, p. 79).

Como se nota, não fica claro se $U$ tinha planejado a viagem para suicidar-se ou se, simplesmente, o suicídio acontece como uma alternativa extrema de livrar-se das perturbações que o acompanharam ao longo de toda a vida, talvez um traço de loucura. Há um vazio que nem as personagens nem o narrador ou o leitor são capazes de preencher, pois parece situar-se além do humano ou da razão. Se a vida parece mais complicada do que a literatura, como alega o narrador nesse mesmo conto, só pela literatura/arte é que isso se torna visível, ainda que de maneira oblíqua.

Essas personagens são indivíduos sem rumo, nem fim - o paradoxo de sua resistência - e, nesse sentido, apesar dos traumas e das tensões históricas que encarnam, no contexto do exílio provocado pela ditadura de Pinochet, são personagens improváveis, não referenciais - "como casi todo en esta historia, es improbable" (BOLAÑO, 2001, p. 32), dirá o narrador em "Gómez Palacio" a respeito de uma possível ação sua. No todo, a narrativa não aponta para o desenvolvimento de um estado de sujeito, para as personagens. Ao contrário, passado o momento de superioridade de $\mathrm{B}$, no ensaio de briga com $\mathrm{U}$, ele começa a mudar a imagem que tem de $\mathrm{U}$, o qual, por sua vez, passa de grande e quase fantasmagórico, no início do relato, a pequeno e frágil, ao final da história narrada. Uma noite em que caminha pelas Ramblas, encontra $U$ e sua mulher. $\mathrm{B}$ e U não sabem exatamente o que dizer um ao outro. $B$ pensa que $U$ está fingindo simpatia, pois "es como si U lo viera por primera vez" (BOLAÑO, 2001, p. 68). Novamente, do encontro resta algo que $B$ não é capaz de decifrar, apesar de surpreender-se, mais tarde, no mesmo dia, pensando em $U$ (que não mais Ihe parece um inimigo ou alguém que ele deva odiar):

Al despedirse la mujer de $U$ lo besa en la mejilla. $U$ le da un apretón de manos. Nos veremos pronto, dice.// Cuando se queda solo, B piensa que $U$ ya no le parece tan alto ni tan fuerte como en la fiesta, de hecho es solo un poco más alto que él. La imagen de su mujer, por el contrario, ha crecido y ha ganado brillo hasta un nivel insospechado. Esa noche a B, por motivos ajenos a este encuentro, le cuesta conciliar el sueño y en un momento de su insomnio vuelve a pensar en U (BOLAÑO, 2001, p. 69).

Num processo em que novas conexões - encontros, imagens e a própria reflexão de $B$ - criam novas redes de afetos, $B$ os humaniza. Por um lado, certo erotismo da mulher de $U$ desperta-lhe o interesse ou ao menos a atenção, e por outro U parece-lhe, agora, uma pessoa qualquer, como 


\section{1}

ele talvez - cheio de questões não resolvidas ao longo da vida -, porém não necessariamente uma ameaça. Ainda que, no plano dos afetos, o conflito anteriormente instalado se converta em outra coisa, é o sentido do que não se deixa ver totalmente que dá o tom do comportamento das personagens e, mesmo, de B. Depois da festa em que se insinua a possível briga com $\mathrm{U}$, numa de suas digressões, $B$ tem a seguinte impressão acerca da mulher de $\mathrm{U}$ :

imagina también a la mujer de $U$, a la que sólo ha visto una vez y que le parece guapa, con un punto de extrañeza, una mujer que está en otra parte, que saluda (como saludó a B en aquella fiesta) desde otra parte y que mira el telón que aún no se levanta, y a su marido, desde otra parte, un lugar informe tamizado por sus ojos grandes y plácidos (BOLAÑO, 2001, p. 66).

É a condição estranha que a caracteriza, aos olhos do narrador - ainda que seu comportamento com U e a esposa não seja menos esquisito. O procedimento descritivo, que lembra o de Julio Cortázar, ao deter-se em detalhes aparentemente dissociados do andamento da história narrada, aponta para um sentido da existência das personagens: estão sempre fora do seu tempo e fora de lugar, do que emerge a impressão de que estão em outro lugar, como diz acima o narrador. Se, por um lado, poderia tratar-se de uma mera impressão do narrador ou de B ante a impossibilidade de conhecer, de fato, a mulher de U, por outro, a situação corresponde a um traço da experiência e da própria vida da personagem - extensíveis a $U$ e ao próprio narrador, no conto -, que é o estar no meio do caminho (da vida, de seu perambular permanente, etc.).

As ressonâncias, que passam por Dante (1845, p. 200) ("Nel mezzo del cammin di nostra vita", Inferno, I, 1, Divina comédia), Antonio Machado (1984, p.836) ("Caminante, son tus huellas/ el camino y nada más;/ caminante, no hay camino,/ se hace camino al andar", Campos de Castilla, seção "Proverbios y cantares", estrofe 29, versos 1 a 4) ou Carlos Drummond de Andrade (1967, p. 61) ("Tinha uma pedra no meio do caminho"), para o leitor brasileiro, estabelecem um diálogo mais evidente, no entanto, com um ensaio de Julio Cortázar, intitulado, justamente, "Del sentimento de no estar del todo", no qual o escritor argentino comenta, não sem certa ironia, as críticas que seus contos e, mesmo, seu romance Rayuela receberam em razão desse procedimento, que por vezes beira o insólito - no caso de Cortázar. Tanto no escritor argentino quanto em Bolaño, para o caso de "Días de 1978", esse sentimento se associa à abertura a um jogo de forças que escapa à racionalidade e a um realismo circunscrito ao imediato, no universo das personagens, mas também está relacionado a um exercício de busca estética:

Sempre serei como um menino para muitas coisas, mas um desses meninos que, desde o começo, carregam consigo o adulto, de maneira que, quando o monstrinho chega verdadeiramente a adulto ocorre que, por sua vez, carrega consigo o menino, e nel mezzo del cammin dá-se uma coexistência poucas vezes pacífica de pelo menos duas aberturas para o mundo.// Pode-se entender isto metaforicamente porém indica, em todo caso, um temperamento que não renunciou à visão pueril como preço da visão adulta, e essa justaposição, que faz o poeta e talvez o criminoso, e também o cronópio e o humorista (questão de doses diferentes, de acentuação aguda ou esdrúxula, de escolhas: agora jogo, agora mato) manifesta-se no sentimento 


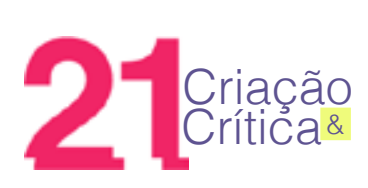

de não estar de todo em qualquer das estruturas, das teias que a vida arma e em que somos simultaneamente aranha e mosca (CORTÁZAR, 2006, p. 165-166).

Cortázar, que Bolaño sempre destacou em seu cânone particular, como se pode ver no conjunto de sua obra, identifica, nesse "meio do caminho" em que não se está totalmente ou se está pela metade, um ponto - talvez o argentino o chamasse de punto vélico - em que a infância e a vida adulta atuam simultaneamente sobre o indivíduo. Se, numa vinculação com Schiller (1995), considerarmos que a infância está para o sensível, porém ainda lhe falta o desenvolvimento da razão, enquanto no adulto se encontra a razão desenvolvida, mas o impulso sensível foi, por vezes, submetido ao racional e, portanto, a criança e o adulto tornam-se polos que não se tocam (natureza e cultura, se quiser), então ficará claro que o "sentimiento de no estar del todo" de que fala Cortázar e que Bolaño retoma em "Días de 1978" corrobora aquele impulso lúdico (não necessariamente divertido, como se sabe) que, segundo Schiller, é responsável pela anulação da relação de submissão entre o sensível e o racional (a criança e o adulto) e que, quando atua, não só potencializa o estado estético no indivíduo, mas também provoca uma indeterminação no tempo, de modo a oferecer-Ihe uma consciência de si e do outro. De fato, no conto de Bolaño em questão, é a partir do momento em que nota que a mulher de $U$ parece estar em outra parte, lembrando-se dela e do evento ocorrido na festa, que $B$, e o sabemos via narrador, opera um duplo movimento de aproximação (ainda que especulativa) do casal e aproximação de si mesmo, em relação a $U$. A curiosidade da criança e a reflexão do adulto, nesse sentido, atuam em $B$ em igualdade, o que potencializa uma elevação moral que, por sua vez, o leva a abandonar a postura de superioridade quase pedante do início da história narrada.

Além disso, como Cortázar insiste no final do fragmento citado, tal justaposição consiste, também, numa consciência estética, segundo ele, frequente, justamente, no artista. No mesmo ensaio, o escritor argentino comenta: "escrevo por não estar ou por estar a meias. Escrevo por falência, por deslocamento; e como escrevo de um interstício, estou sempre convidando que outros procurem os seus" (CORTÁZAR, 2006, p. 166). A declaração poderia ser de B (de Bolaño?) ou do narrador, no conto "Días de 1978". Por sua vez, o "sentimiento de no estar del todo" aponta para o informe.

Nos contos em análise, o informe é uma forma, uma ideia. Pautado no inacabado cujos limites não estão claros do ponto de vista estrutural, como já se insistiu anteriormente, o informe é obtido por meio de uma técnica deliberada, do ponto de vista da criação literária: descrições vagas, instalação da dúvida, amplificação, aproximações e distanciamentos, um girar ao redor daquilo que se comenta sem nunca tocá-lo de fato. Nesse sentido, o "sentimiento de no estar del todo" que o narrador capta em relação à esposa de $U$ se articula à própria materialidade narrativa e se converte naquilo que o conto é. Se nos valermos de uma fórmula pautada nas noções de forma e conteúdo, veremos que aquilo que, no plano do conteúdo, corresponde a um estado das personagens, encontra seu equivalente no plano da expressão: o informe. No âmbito dos motivos dramáticos, isso corresponde à exploração das impressões, dos traços esmaecidos, daquilo que o narrador, ao narrar, em vez de esclarecer, obscurece. Como argumenta Cortázar no mesmo ensaio:

cada vez que o poeta é sensível à sua lateralidade, à sua situação extrínseca numa realidade aparentemente intrínseca, reage poeticamente (quase diria profissionalmente, sobretudo a partir de sua maturidade técnica); dito de outra maneira, escreve 


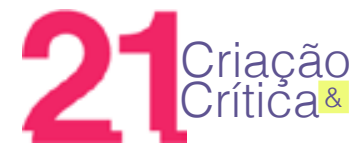

poemas que são como petrificações desse estranhamento, o que o poeta vê ou sente em lugar de, ou ao lado de, ou por debaixo de, ou ao contrário de, remetendo este de ao que os demais vêem tal como crêem que é, sem deslocamento nem crítica interna. Duvido que exista um único grande poema que não tenha nascido dessa estranheza ou que não a traduza; mais ainda, que não a ative e potencialize ao suspeitar de que é precisamente a zona intersticial por onde cabe aceder (CORTÁZAR, 2006, p. 169).

Bolaño segue a mesma perspectiva, no conto em análise, e nisso alinha-se, também, a uma perspectiva de autonomia do literário enquanto forma esférica - expressão que também é de Cortázar (2006) -, cujas relações com o que lhe é exterior não desaparecem, porém passam por um procedimento de despersonalização (ELIOT, 2000) que as converte em percepção que se pretende universal. Deste modo, à indeterminação ou ao inapreensível das situações dramáticas, em "Días de 1978", Bolaño responde com a própria escrita (forma informe) que, concretamente, expressa, por meio de uma técnica, o deslocamento e o "sentimiento de no estar del todo".

Procede-se, então, no conto, a um exercício de equilíbrio entre diferentes impulsos, de modo que a narrativa vai, aos poucos, convertendo certo patetismo dos eventos narrados em parte integrada ao próprio relato, que, ao apresentar-se dessa maneira, deixa claro que não poderia apresentar outra configuração: a forma que se impõe à matéria. Mais uma vez, Bolaño mostra-se afeito a uma concepção do literário como sendo capaz de ir em busca de sua própria forma e, deste modo, impor-se ao mundo. Sabemos que tal efeito é o resultado de um exercício escritural, mas a concepção não deixa de ser relevante, em nossa discussão, porque põe em evidência o artista e a própria forma (enquanto ideia), no campo da literatura contemporânea. Há que notar, quanto a isso, que o informe constitui-se numa imagem constante em "Días de 1978", mas também no conjunto dos contos de Putas asesinas. Falando das andanças de B com uma dinamarquesa (K) que conhece em Barcelona, o narrador comenta: "Después los tres, o los cuatro, se hunden en una oscuridad informe" (BOLAÑO, 2001, p. 70), por exemplo.

Também está claro que um dos procedimentos importantes para a configuração do informe, nos relatos do livro, é o recurso a uma comunicação que falha, que se interrompe, que está marcada pelo não dito ou pelo entredito e que, nesse sentido, deixa sem forma definida a própria linguagem das personagens. Esse traço torna-se evidente em "Vagabundo en Francia y Bélgica", mas é visível, também, em "El Ojo Silva" e em "Días de 1978", como já mencionamos anteriormente. As próprias personagens muitas vezes não têm nome, e são designadas por letras ( $U$, $B$, $\mathrm{K}$, etc.), podendo ser cada uma delas um anônimo qualquer, na precariedade dessa linguagem que não é capaz de captá-las em sua totalidade.

Este terceiro conto está marcado pelos mesmos motivos dramáticos dos anteriores, e como fica sugerido já pelo título, é o vagar do protagonista pela Europa que se constitui no tema da história narrada, seu perambular numa espécie de melancolia do mundo. O narrador insiste em observar, ao longo de todo o relato, que B (como este personagem também se chama) caminha sem rumo. É, pois, o submundo, em certa vertente baudelairiana, que ecoa nas andanças de B: as ruas de Paris, a figura do vagabundo, do artista, da prostituta, certo fastio do presente que se coaduna ao Spleen, na obra do poeta francês. 


\section{1}

Mas, nesse vagar em que a personagem joga o jogo de sua vida, a imagem do acaso manifesta-se como expressão da linguagem, modo obscuro da/na comunicação humana. Com ressonâncias mallarmaicas, na linguagem de Bolaño, nesse conto, um lance de dados jamais abolirá o acaso, por isso, traçar destinos, elaborar diálogos, prever eventos e acontecimentos constituemse em práticas que as personagens se eximem de fazer, talvez por intuírem que, como elas, o acaso também joga seu jogo. Numa livraria de livros usados, em Paris, B descobre uma revista chamada Luna Park e, folheando-a, depara-se com vários nomes, sendo o de Henri Lefebvre o único que ele desconhece por completo, nunca lera nada de sua autoria. Depois disso,

se pierde por las calles de París, adonde ha ido a perderse, para ver pasar los días [...], y al caminar con la revista Luna Park dentro de una bolsita de plástico que cuelga perezosamente de su mano, la imagen se ocluye, como si esa vieja revista [...] concitara o produjera un eclipse. El eclipse, B lo sabe, es Henri Lefebvre. El eclipse es la relación entre Henri Lefebvre y la literatura. O mejor dicho: el eclipse es la relación entre Lefebvre y la escritura (BOLAÑO, 2001, p. 83).

Seus passos, a partir de então, seguirão pistas em busca de histórias, textos e memórias de Lefebvre ao longo do relato. "A veces toma notas, pero por regla general no escribe" (BOLAÑO, 2001, p. 81), como se a linguagem fosse insuficiente para dar conta de suas inquietações, ao mesmo tempo em que é a única via possível para satisfazê-las, na escritura. Torna-se evidente, nisso, que B e Bolaño se sobrepõem, no relato. Essa é uma busca da linguagem (a sua, a de Lefebvre). Por um lado, a linguagem identificada ao acaso e à busca configura-se, pois, como espaço e lugar para a divagação, o ir e vir sem rumo nem destino certo, linguagem desinteressada, portanto, não instrumentalizada. Nesse sentido, a linguagem dá vazão a um propósito do narrador: perder-se. Esse é um modo de encontrar-se, paradoxalmente, na escritura e no narrar. Assim como o caminhar sem rumo, essa escrita que passa de um subtema a outro e entrega-se ao acaso constituise num lugar de liberdade, o outro do exílio. Por outro lado, a linguagem mobilizada para uma comunicação objetiva aniquila-se, deixando margem ao silêncio, no conto.

B lembra-se de uma amiga que vive em Bruxelas e decide visitá-la. M, como é designada a amiga, na história narrada, surpreende-se com a visita, mas os contatos tornam-se agradáveis entre ambos. A comunicação, entretanto, limita-se a uma superficialidade que parece afastá-los, em vez de aproximá-los. Logo após o encontro e os cumprimentos: "Finalmente no tienen nada que decirse y se quedan callados. El silencio le sienta bien a M" (BOLAÑO, 2001, p. 84). No dia seguinte, M liga para $B$ e, sem muita conversa, Ihe diz que vai buscá-lo para que possam passear. Vão juntos a vários pontos da região, prática que se repete nos demais dias. Com certa frequência, "B cree que M quiere decirle algo, pero finalmente se queda callada" (BOLAÑO, 2001, p. 90), e ocorre a mesma coisa com ele. Chegam a ir juntos a Masnuy Saint-Jean, cidade natal de Lefebvre, ainda que $M$ não entenda bem as razões do interesse de $B$ pelo escritor francês. No local onde supostamente vivera o escritor, não encontram nem sinal de sua história. A conversa com os moradores dispersa-se ( $M$ fala com uma mulher sobre o cabelo que esta está pintando, e $B$ apenas Ihe pergunta desde quando os moradores da suposta casa que foi de Lefebvre vivem nela). $O$ domínio da linguagem, para B, só se dá no âmbito da escritura - no ir e vir em que, pela imaginação, inscreve-se numa 


\section{1}

relação de gozo com a língua. Nesse sentido, B se aproxima do albatroz do poema homônimo de Baudelaire - mestre em seu lugar, e totalmente deslocado fora dele.

Por sua vez, a incapacidade de B (mas também de M) para o estabelecimento de uma comunicação duradoura ou estável frustra uma aproximação efetiva entre ambos - aparentemente desejada pelos dois, dadas as sugestões de certo erotismo que se insinua entre ambos, no pouco tempo que duram esses dias de encontro, em Bruxelas. Em meio ao caminhar infinito, a breves experiências sexuais com prostitutas e muita solidão entremeada, B apenas constata que não tem mais nada a fazer aonde quer que vá: Bruxelas, Paris, etc. Seu território, o único onde a vida é capaz de oferecer-Ihe liberdade e um sentido de beleza, é o da linguagem dedicada a si mesma, a provocar aquele eclipse que o próprio $B$ tinha identificado à escritura, quando abriu pela primeira vez a revista e descobriu Lefebvre. Talvez por isso Ihe interesse menos encontrar Lefebvre do que a busca, que é o que conduz o jogo da/na linguagem que ele se dispôs a jogar. Não por acaso, o relato termina como uma indagação sobre a linguagem, sobre Lefebvre, mas, principalmente, sobre a incomunicação, no universo das personagens. Depois de voltar a Paris, de contemplar-se no espelho, no dia seguinte liga para M:

No esperaba encontrarla. No esperaba encontrar a nadie. Sin embargo, alguien descuelga el teléfono. Soy yo, dice B. ¿Cómo estás?, dice M. Bien, dice B. ¿Has encontrado a Lefebvre?, dice M. Debe de estar dormida aún, piensa B. Luego dice: no. Me ríe. Su risa es bonita. ¿Por qué te preocupas por él?, dice sin dejar de reírse. Porque nadie más lo hace, dice B. Y porque era bueno. Acto seguido piensa: no debí decir eso. Y piensa: $\mathrm{M}$ va a colgar. Aprieta los dientes, involuntariamente su rostro se contrae en un gesto de crispación. Pero M no cuelga el teléfono (BOLAÑO, 2001, p. 96).

O fragmento, que é o trecho final do conto, apresenta a linguagem naquilo que ela porta de vazio (quase o máximo possível de vazio), momentos fáticos em que nada se comunica, de fato. Por um lado, o diálogo é meio patético, ao deixar entrever o interesse de um pelo outro que, no entanto, não avança pela falta de habilidade de B. Por outro lado, o procedimento corrobora a ideia da linguagem sempre aberta ao acaso, cuja enunciação irrompe, cada vez, como algo novo que esta aí apenas como rastro de si mesma, prova da própria existência não submetida a normas ou sistemas apriorísticos e, por isso, lugar de resistência (RANCIĖRE, 2007), de sobrevivência (DIDI-HUBERMAN, 2011), lugar de expressão daquilo que não tem lugar, do que não se deixa apreender totalmente, do próprio silêncio como ato de fala.

\section{A marginalidade: uma ética do artista e da arte}

$O$ último fragmento de Bolaño citado acima sintetiza toda uma ética do escritor, que se pode observar nos demais contos aqui comentados: quando $\mathrm{M}$ Ihe pergunta o porquê de sua busca por Lefebvre, ele the responde que é "Porque nadie más lo hace" (BOLAÑO, 2001, p. 96). Fazer algo "Porque nadie más lo hace" também pode ser, e frequentemente é, na narrativa do autor, loucura, crueldade, vaidade, egoísmo. Mas o fragmento também resume numa frase a sua prática como crítico-ficcionista e ensaísta que se dedicou a escavar, na literatura, nomes e obras de autores por vezes quase esquecidos ou pouco lidos, em razão das ações do mercado ou, mesmo, dos caminhos trilhados pela crítica literária, mas que, segundo ele, constituem, de fato, a literatura 


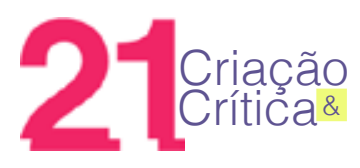

que vale a pena ler. Posicionamentos contundentes a esse respeito podem ser vistos, por exemplo, em "Los mitos de Ctchullu" ou em "Literatura + enfermedad = Enfermedad", de El gaucho insufrible. Ou aquilo que se expressa em "Vagabundo en Francia y Bélgica", na procura de B por Henri Lefebvre, que se torna sinédoque da busca pelo desconhecido, pela arte, pelo artista e pela própria escritura. Seu exercício como leitor e crítico implica uma espécie de exercício de escavar, encontrar para salvar aquilo que o mercado ou o acaso relegaram ao esquecimento.

É por esse enfrentamento às instituições, no campo da arte, que iniciamos este texto como uma epígrafe extraída de uma carta do pintor francês Gustave Courbet e sugerimos que ela poderia conter uma postura característica, também, de Bolaño. Seja pela relação oblíqua entre o individual e o coletivo, entre o subjetivo e o objetivo ou, especialmente, pela afirmação de uma ideia do artista e da arte em face do mundo, Bolaño se assemelha a Courbet de tal modo que poderíamos, a partir do pintor e sua obra, esboçar as dimensões da ética da literatura de Bolaño.

Como vimos anteriormente, as bases dessa ética ancoram-se na errância, no inapreensível e nos silêncios. Se bem que Courbet, que criou obras pautadas em certo tipo de realismo, não possa ter sua arte caracterizada como inapreensível, ele mesmo distante de uma postura silenciosa, como ressalta Coli (2007), os dois artistas se aproximam na opção pela marginalidade, que confere ao artista um lugar singularmente livre. Como lembra Jorge Coli, a arte de Courbet marca "seu afastamento desses critérios externos que possuem valores já constituídos, e o estabelecimento, para o artista, de um lugar independente, que lhe é próprio" (COLI, 2007, p. 407). Esse lugar é a marginalidade. Há nessa postura, em Bolaño, traços da anacorese, tal como entendida por Barthes em Como viver junto: "fundada por um ato de ruptura, um ímpeto de partida. [...] uma ação, uma linha, um limiar a ser ultrapassado" (BARTHES, 2013, p. 47). Essa ruptura também pode ser pensada em termos de uma busca de liberdade e de enfrentamento às formas de poder: idiorritmia, nos termos de Barthes (2013), enquanto questão de marginalidade, de relação negativa com o poder, de busca do rhythmós, o ritmo imperfeito, flexível, próprio.

Deste modo, a marginalidade do artista corresponde ao lugar daquele que não deve mais nada a ninguém ou, no caso do artista representado nos três contos considerados mais especificamente neste estudo, daquele que não tem mais razões para dar claras explicações a ninguém, pois ou perdeu aquilo que tinha (origem, pátria, família, utopias políticas, etc.) ou já se deparou com a face mais obscura do humano e, por isso, experimenta um mal-estar incomparável que o faz colocar-se no mundo de modo menos preso às normas sociais. É nesse sentido, também, que novamente Bolaño se aproxima da concepção do artista afirmada em Courbet, visto que, em tal perspectiva, o artista, "ao mesmo tempo independente e consciente da elevação de sua tarefa artística, é obrigado, para manter-se à altura de si mesmo, a construir uma ética para si" (COLI, 2007, p. 408).

Em Bolaño essa ética é construída a partir do deslocamento, o artista que não tem lugar no mundo, mas encontra na arte um lugar onde ele é superior, algo que também se pode constatar em Courbet - pense-se, por exemplo, em seu famoso quadro Bom dia, senhor Courbet! (1854). Não por acaso, suas personagens e narradores identificados com o universo da arte portam, por vezes, um ar de superioridade que beira o esnobismo ou o egoísmo. Diferenciam-se desse quadro do pintor francês, no entanto, porque em Bolaño, a afirmação do artista não se dá por deferência, como na tela de Courbet, e sim pela falta de qualquer outro caminho potente para a vida e a subjetividade, exceto a arte e a vida. 


\section{1}

É nesse sentido que há uma militância em Bolaño: trata-se de uma afirmação de comportamentos excêntricos ou estranhos, de uma prática da literatura que faz do artista um sobrevivente e da arte uma alternativa para a aproximação daquilo que, na vida ordinária, se manifesta, porém não se deixa captar pelo indivíduo de outro modo. Não há, quanto a isso, separação entre arte e vida, na literatura do autor. Lemos em "Dentista", outro conto de Putas asesinas:

El arte, dijo, es la historia particular. Es la única historia particular posible. Es la historia particular y es al mismo tiempo la matriz de la historia particular. ¿Y qué es la historia particular?, dije. Acto seguido pensé que me respondería: el arte. [...] Pero mi amigo dijo: la matriz de la historia particular es la historia secreta.// [...] ¿Y tú te preguntarás qué es la historia secreta?, dijo mi amigo. Pues la historia secreta es aquella que jamás conoceremos, la que vivimos cada día, pensamos que vivimos, pensando que lo tenemos todo controlado, pensando que lo que se nos pasa por alto no tiene importancia, buey! Lo que pasa es que no nos damos cuenta. Creemos que el arte discurre por esta acera y que la vida, nuestra vida, discurre por esa otra, y no nos damos cuenta de que es mentira (BOLAÑO, 2001, p. 179).

Tal postura, que também lembra a de Baudelaire - a beleza, a arte, extraída do submundo, do menor, e a própria figura do artista concebida como estética, o artista como raro, etc. -, distanciase, no entanto, do poeta francês, na medida em que não há um sublime a ser buscado nem o heroísmo da sociedade industrial a ser extraído da banalidade da vida cotidiana das personagens, em Bolaño. Ao contrário, na literatura do chileno a banalidade figura ao lado de acontecimentos intraduzíveis na linguagem, e apenas o mal-estar emerge como aquilo que é próprio dos homens e os aproxima, de certo modo. Nesse ponto, Bolaño também se afasta de Courbet, para quem a negação das instituições - no ápice da sociedade burguesa oitocentista, na França - culmina na afirmação do artista, ao passo que, para o escritor chileno, a procura do artista diz respeito ao total descrédito das instituições (inclusive a literatura, quando submetida a determinações que the são exteriores).

É importante que se note essa diferença, tendo em vista que partimos de Courbet para discutir a ética da literatura de Bolaño, pois enquanto naquele a ética centra-se no papel conferido ao artista, em razão do gesto instaurador que este realiza (COLI, 2007) - Cf. Bom dia, senhor Courbet! ou $O$ ateliê do pintor (1855) -, de modo que o que se celebra é o próprio artista, em Bolaño o que se põe em evidência é a procura do artista e de sua arte, como se tematiza, por exemplo, em "Vagabundo en Francia y Bélgica", a respeito de Henri Lefebvre. Como lembra Michael,

é o poeta transformado em detetive, e [...] eu acrescentaria que seu personagem essencial é o poeta de vanguarda: o poeta como jovem rebelde que tem a ilusão, ou que vende a mentira, de que a literatura atual pode ser exterminada para ser inventada de novo. A vanguarda como modificação da ordem dos clássicos, a vanguarda como a modificação da linguagem e, sobretudo, a vanguarda como um modo de vida (MICHAEL, 2017, p. 12). 


\section{1}

Em Courbet, há certa euforia em relação à figura do artista, enquanto em Bolaño é a própria busca que figura como motor da existência (do relato, do narrador, da própria literatura, portanto). Deste modo, pode-se dizer que Bolaño investe numa ética que é, simultaneamente, do artista sempre deslocado, marginal, errante, avesso a concessões - e da arte, enquanto lugar em que o sensível e o racional e aliam a partir de um impulso múltiplo, o lúdico (SCHILLER, 1995), para constituir-se em signo de liberdade.

Bolaño inscreve-se numa ética de exigências estéticas, que implica certa renúncia em relação ao mundo, o que torna a marginalidade um traço essencial, nos contos lidos aqui. Novamente como em Courbet, o artista é "obrigado a estabelecer uma ética da fidelidade à sua arte, isto é, eu renuncio ao meu lugar no mundo porque eu sei que o meu lugar é no universo da arte, e ele vale o meu sacrifício" (COLI, 2007, p. 421). Tal postura torna-se emblemática em Bolaño, se nos lembrarmos de que o ritmo de escrita nos últimos dez anos de sua vida foi intenso, de modo quase dramático já ao final, quando sua saúde estava fragilizada e ele sabia que podia morrer em breve (GUTIÉRREZ, 2007; MAGRI, 2013). Nesse atirar-se rumo ao desconhecido em busca de si (como artista) e da própria obra, o vazio

estaria próximo da angústia existencial dos protagonistas: errantes, deslocados, exilados inclusive em sua própria terra, e de sua experiência do mal, da morte, do desencanto violento das desilusões. Já que é impossível falar daquilo que está no outro lado do humano, da experiência do "mal profundo", o escritor só tem dois caminhos: 1) contá-lo até o infinito, recontar, exercício de re-escritura constante; ou 2) o silêncio (GUTIÉRREZ, 2007, p. 4).

Ainda que o silêncio, naquilo que porta de incomunicável, seja um motivo frequente em suas narrativas, não é pelo silêncio que Bolaño opta, de fato. A obsessão pelos mesmos temas ou a extensão de seu último romance - 2666 - o mostram. Ele investe no único modo legítimo, de acordo com a perspectiva ética que adota, de o escritor agir, em algum nível, sobre o mundo e a realidade que o cerca: na literatura, na linguagem (mesmo precária), na escritura.

\section{Referências}

ALIGHIERI, D. La divina commedia. Firenze: Societa editrice fiorentina, 1845.

BARTHES, R. Como viver junto. Trad. Leyla Perrone Moisés. São Paulo: Martins Fontes, 2013.

BAUDELAIRE, C. Sobre a modernidade. São Paulo: Paz e Terra, 1997.

BOLAÑO, R. Putas asesinas. Barcelona: Anagrama, 2001.

COLI, J. "Bom dia, senhor Courbet!" In: NOVAES, A. (org.) Ética. São Paulo: Companhia das Letras, 2007. p. 407-424.

CORTÁZAR, J. Valise de cronópio. São Paulo: Perspectiva, 2006.

DIDI-HUBERMAN, G. Ante el tiempo: historia del arte y anacronismo en las imágenes. 3. ed. Trad. Antonio Oviedo. Buenos Aires: Adriana Hidalgo, 2011.

DRUMMOND DE ANDRADE, C. Obra Completa. 2. ed. Rio de Janeiro: José Aguilar, 1967.

ELIOT, T. S. La tradición y el talento individual. In: Ensayos escogidos. Trad. Pura López Clomé. México, D. F.: UNAM, 2000. p. 17-29. 


\section{1 tringa}

FOUCAULT, M. As palavras e as coisas. 9. ed. São Paulo: Martins Fontes, 2007.

GUTIÉRREZ, R. "Roberto Bolaño: fragmentos de um discurso do vazio". Revista Escrita, PUCRJ Online, v. 8, p. 11-22, 2007.

HERRERA-ÁLVAREZ, R. G. "Roberto Bolaño: conselhos sobre a arte de escrever contos". In: DIAS, M. H. M.; PITERI, S. H. O. R. (Org.). A literatura do outro e os outros da literatura. São Paulo: Cultura Acadêmica - Editora UNESP, 2010. p. 65-94.

KLINGER, D. Literatura e ética: da forma para a força. Rio de Janeiro: Rocco, 2014.

LUKÁCS, G. "O romance como epopeia burguesa". In: Arte e sociedade: escritos estéticos (1932-1967). Trad. Carlos Nelson Coutinho e José Paulo Netto. Rio de Janeiro: UFRJ, 2009. p. 193-243.

Teoria do romance. Trad. José Marcos Mariani de Macedo. São Paulo: Duas Cidades/Editora 34, 2000.

MACHADO, A.; MACHADO, M. Obras completas de Manuel y Antonio Machado. 2. ed. Madrid: Bilioteca Nueva, 1984.

MAGRI, I. "Literatura e autonomia: uma leitura a partir do posicionamento de Roberto Bolaño". Landa, v. 1, n. 2, p. 18-31, 2013.

MICHAEL, C. D. Bolaño, Benjamin, Walser: três ensaios. Rio de Janeiro: Papéis Selvagens, 2017.

POUILLON, J. O tempo no romance. São Paulo: Cultrix, 1974.

RANCIÉRE, J. "Será que a arte resiste a alguma coisa?" In: LINS, D. (Org.). Nietzsche, Deleuze, arte, resistência. Rio de Janeiro: Editora Forense Universitária, 2007. p. 126-140.

SCHILLER, F. A educação estética do homem: numa série de cartas. São Paulo: Iluminuras, 1995.

SUZUKI, M. "O belo como imperativo" (introdução). In: SCHILLER, F. A educação estética do homem: numa série de cartas. São Paulo: lluminuras, 1995. p. 11-19.

Recebido em: 24/04/2018 Aceito em: 06/09/2018

Referência eletrônica: ALVES, Wanderlan. Orfandade, movimento, presença. Sobre uma ética da literatura em Putas asesinas, de Roberto Bolaño. Criação \& Crítica, n. 21, p.127-146, nov. 2018. Disponível em: <http://revistas.usp.br/criacaoecritica>. Acesso em: dd $\mathrm{mmm}$. aaaa. 